\title{
Forum Sociológico
}

Série II

23 | 2013

Número 23

\section{Editorial}

João Sedas Nunes

\section{OpenEdition}

Journals

Edição electrónica

URL: https://journals.openedition.org/sociologico/850

DOI: 10.4000/sociologico.850

ISSN: 2182-7427

\section{Editora}

CICS.NOVA - Centro Interdisciplinar de Ciências Sociais da Universidade Nova de Lisboa

Edição impressa

Data de publição: 1 novembro 2013

Paginação: 7

ISSN: 0872-8380

\section{Refêrencia eletrónica}

João Sedas Nunes, «Editorial», Forum Sociológico [Online], 23 | 2013, posto online no dia 01 janeiro 2014, consultado o 03 abril 2022. URL: http://journals.openedition.org/sociologico/850 ; DOI: https:// doi.org/10.4000/sociologico.850

Este documento foi criado de forma automática no dia 3 abril 2022.

(c) CICS.NOVA 


\title{
Editorial
}

\author{
João Sedas Nunes
}

1 O presente número - 23 - diverge do formato editorial que tem pautado a Forum Sociológico desde que, em 1999, a sua II $^{a}$ série foi inaugurada. A novidade é que o número não contém dossiê, sendo integralmente composto por artigos avulsos, precisamente onze. Esta especificidade, porém, não significa uma inflexão "singularista" da política editorial da Forum Sociológico. Já no próximo número retomar-se-á o modelo que recobriu os primeiros vinte e dois números da II ${ }^{a}$ série.

2 A inexistência de um dossiê, reconheça-se: sempre fonte de (acrescido) concerto e consistência, propiciou uma excecional pluralização do conteúdo do número que ora se publica. No domínio dos artigos, compreende temas diversos embora não raro convergentes quer quanto ao objeto tratado (escola, classes sociais, práticas culturais, etc.) quer quanto a perspetivas de análise empregues (preponderando enfoques construtivistas). Brevemente, abordam-se neste número: os efeitos que a retração do Estado Social em Portugal exerce sobre as formas institucionais que se acomodam na provisão da alimentação escolar pública; o papel supletivo das solidariedades familiares à proteção social do Estado perante o desemprego; as práticas e as disposições cultivadas dos jovens das classes dominantes; a sobredeterminação "individualista" das identidades de classe contemporâneas; a centralidade do consumo nas construções identitárias contemporâneas; a análise de processos de gentrificação polarizados na estruturação da ludicidade urbana noturna; as (in)determinações da participação pública e dos seus protagonistas; as inscrições semânticas e conceptuais da noção de fronteira e as suas potencialidades heurísticas; a diversidade dos regimes de acção pedagógica que envolvem as TIC (Tecnologias de Informação e Comunicação) acionados em contextos escolares; last but not least, a penetração dos juízos críticos estudantis por gramáticas morais plurais como meio para restituir culturas escolares incompreensíveis à perceção adulta.

3 A par deste conjunto de artigos o n. 23 inclui o texto integral da conferência de abertura do ano escolar de 2011/12 da Sociologia da Nova, proferida por Augusto Santos Silva, intitulada Processos no tempo: uma reflexão sobre o valor que a história acrescenta à sociologia, a partir do magistério de Vitorino Magalhães Godinho, muito justamente dedicada 
a este último falecido em 26 de Abril de 2011. Dir-se-á, com rigor, mais um objeto a densificar a heterogeneidade que carateriza o número.

Mas não é só - ou tanto! - pela originalidade destacada que este número é da maior importância para todos aqueles que têm responsabilidades na sua edição. Há duas outras razões que se lhe sobrepõem.

5 Por um lado, este é o número que põe a revista em dia - no seu momento mais difícil publicámo-la quase com três anos de atraso - ao mesmo tempo que auspicia o regresso à periodicidade semestral que queremos ainda este ano (2013) concretizar.

6 Por outro lado, o n. 23 constitui também - importa ressaltá-lo - o segundo a dar à estampa sem quaisquer condicionalismos (quanto a custo de acesso e diferimento temporal) em http://www.sociologico.revues.org. Como se não fosse motivo bastante de regozijo, esta possibilidade de associação ao sítio revues.org, proporcionada por colaboração preciosa com o projeto/portal OpenEdition (http://www.openedition.org/), a cuja equipa estamos deveras gratos, permite à revista inscrever-se numa banda de indexação bem mais ampla do que antes acontecia. Além dos motores de busca gerais (Google) e científicos (Google Scholar, Base, OAIster, Scirus), a revista passa a integrar listas de ligações especializadas (Intute, DOAJ) e bases de dados científicas nacionais e internacionais (Sudoc, WorldCat, EZB, Journal TOCs). Acresce a sua inclusão nos catálogos dos prestadores de serviços a bibliotecas (Serials Solutions, Ex-Libris).

7 Estamos, aliás, em crer que o mais tardar em 2014 haverá (mais) novidades quanto à indexação da revista.

8 Estão assim, cremos, criadas as condições logísticas para que a Forum Sociológico se possa firmar como um dos periódicos de ciências sociais publicados em língua portuguesa de referência internacional, atraindo leitores exigentes e autores prestigiados.

9 Fica aqui o convite a tod@s para que nos visitem e connosco colaborem, lendo a revista, enviando originais para publicação, recensões críticas ou comentários, e dando a conhecer os seus conteúdos através das redes científicas e sociais em que estão inseridos. 